\title{
Chirurgia robotowa: nowa jakość i przełom w leczeniu czy kosztowny gadżet?
}

\author{
Wojciech Witkiewicz
}

\section{Robotic surgery - a new quality and breakthrough or an expansive gadget?}

Publikacja na podstawie wystąpienia podczas I Konferencji Naukowej czasopisma Nowotwory "Debaty Onkologiczne" 5 i 6 kwietnia 2013 roku.

I confess that I like doing robotic surgery. I like being able to see, I like the ergonomics, and I do not miss the bleeding. Is this a bad thing? (Mani Menon)

Ostatnie 3 dekady były okresem dynamicznego rozwoju technik małoinwazyjnych stosowanych w dziedzinach zabiegowych. Techniki laparoskopowe, endoskopia i techniki wewnątrznaczyniowe pozwalają dziś uniknąć rozległego nacięcia powłok brzucha pacjenta. Co jest jednak znacznie ważniejsze, zastosowanie technik małoinwazyjnych zmniejsza ból pooperacyjny, skraca pobyt pacjenta w szpitalu i powrót do pełnej aktywności ruchowej.

W roku 2000 w Stanach Zjednoczonych, a następnie w Europie Zachodniej, pojawiło się w praktyce klinicznej nowe narzędzie chirurgii małoinwazyjnej — robot da Vinci (ryc. 1).

System da Vinci jest w istocie zaawansowanym manipulatorem chirurgicznym. Składa się z 3 podstawowych elementów: konsoli chirurgicznej, toru wizyjnego i wieloramiennego manipulatora, którego końcówki (ramiona) są umieszczane w ciele pacjenta. Konsola chirurgiczna jest miejscem, za którym zasiada operujący chirurg. Konsola wyposażona jest w binocular, przez który operator obserwuje obraz pola operacyjnego przekazywany z kamery wprowadzanej do wnętrza jamy brzusznej pacjenta. Operator, używając manetek i pedałów, steruje ruchami ramion robota. Najbardziej unikalnym elementem systemu da Vinci

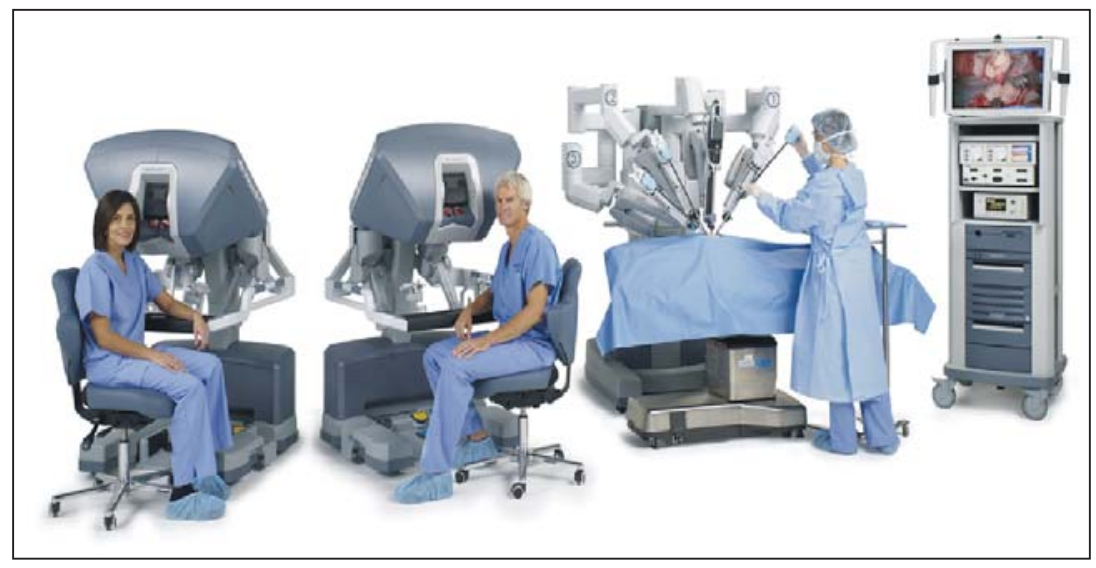

Rycina 1. System da Vinci

Ośrodek Badawczo-Rozwojowy

Wojewódzki Szpital Specjalistyczny

we Wrocławiu 


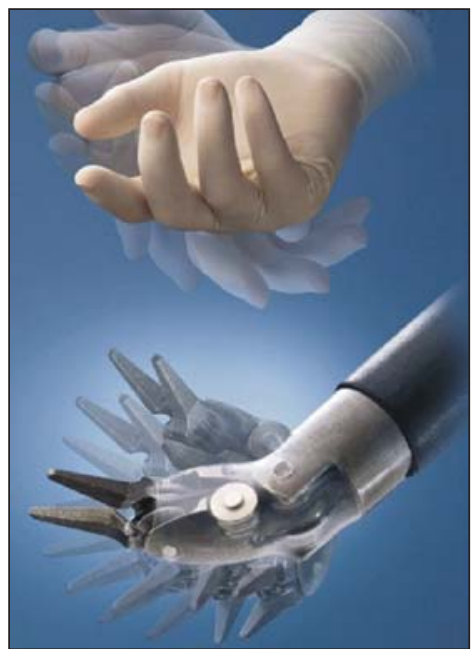

Rycina 2. Zakres ruchu narzędzi systemu da Vinci

jest konstrukcja narzędzi robotowych i sposobu, w jaki się nimi steruje. Narzędzia robotowe (EndoWrist instruments) umożliwiają wykonywanie ruchów w 7 płaszczyznach, co pozwala manipulować nimi w sposób przypominający ruchy ludzkiego nadgarstka (ryc. 2)

System da Vinci początkowo znalazł zastosowanie w kardiochirurgii, stopniowo jednak zyskał również popularność w urologii , ginekologii i chirurgii ogólnej. W roku 2012 liczba robotów pracujących w szpitalach na całym świecie przekroczyła 2,5 tysiąca (ryc. 3).

W tym samym roku z pomocą robota wykonano łącznie 450 tysięcy operacji (ryc. 4). Do najczęściej wykonywanych należały operacje z zakresu ginekologii, urologii i chirurgii ogólnej.

Pierwszy system chirurgiczny w Polsce został zainstalowany w Wojewódzkim Szpitalu Specjalistycznym we Wrocławiu, w Ośrodku Badawczo-Rozwojowym (WSS), w grudniu 2010 r. [1]. Zespół chirurgiczny WSS przebył intensywne szkolenia w ośrodkach robotowych w Europie i USA. Od grudnia 2010 r. do czerwca 2013 r. wykonano ogółem 122 operacje z zastosowaniem robota da Vinci [2] (tab. I). Do najczęściej wykonywanych operacji należały radyklane prostatektomie z powodu raka stercza, resekcje jelita grubego w przypadku raka odbytnicy lub okrężnicy, histerektomii

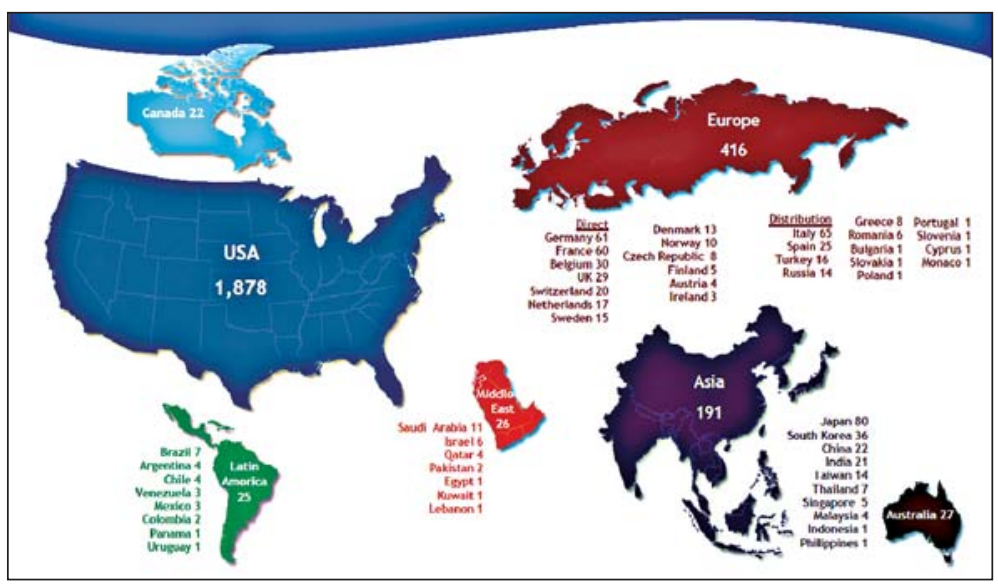

Rycina 3. Liczba robotów chirurgicznych z ich rozmieszczeniem na świecie w roku 2012

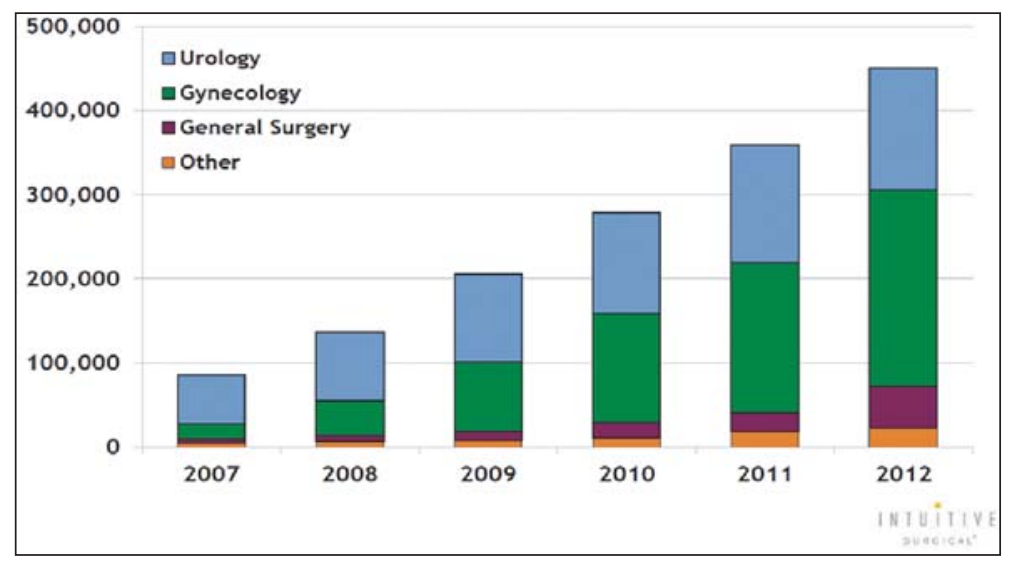

Rycina 4. Liczba operacji przeprowadzonych z asystą robota da Vinci na świecie w kolejnych latach, z podziałem na poszczególne specjalności 
Tabela I. Operacje z zastosowaniem robota wykonane w WSS w latach 2010-2013

\begin{tabular}{lc}
\hline Radyklana prostatektomia & 38 \\
Operacje jelita grubego & 25 \\
Histerektomia & 13 \\
Splenektomia & 10 \\
Adrenelektomia & 5 \\
Operacje bariatryczne & 9 \\
Usunięcie nerki całkowite lub częściowe & 6 \\
Cholecystektomia & 14 \\
Pobranie nerki od żywego dawcy & 1 \\
Wszczepienie protezy Y & 1 \\
\hline
\end{tabular}

w przypadku raka endometrium. W naszej opinii zalety robota da Vinci są najbardziej widoczne w skomplikowanych operacjach, wymagających precyzyjnego preparowania tkanek lub szycia wewnątrz jamy brzusznej [3-7].

\section{Urologia}

Odkąd w maju 2000 r. we Frankfurcie nad Menem przeprowadzono pierwszą robotową prostatektomię radykalną, chirurgia robotowa znalazła swoje poczesne miejsce w urologii, nie tylko onkologicznej.

Prostatektomia radykalna(RALP) jest dziś najczęściej wykonywaną robotową procedurą urologiczną. Tą techniką w USA w 2003 r. zoperowano 9,3\% chorych na raka stercza, poddanych prostatektomii radykalnej.W 2007 r. było to 43\%, w 2009 - 60\%, zaś w 2011 r. - blisko 80\%.

Zastosowań systemu robotowego da Vinci w urologii jest znacznie więcej: cystoprostatektomia radykalna, nefrektomia — radykalna, częściowa i prosta, pobieranie nerek do przeszczepu od żywych dawców, naprawa połączenia miedniczkowo-moczowodowego, adrenalektomia, leczenie przetok pęcherzowo-pochwowych i wiele innych [8].

Prostatektomia radykalna jest doskonałym przykładem, jak technika robotowa może poprawić wyniki leczenia operacyjnego. Zaletą tej techniki operacyjnej, w porównaniu z otwartą prostatektomią radykalną, jest doskonała trójwymiarowa wizualizacja okolicy operowanej, precyzyjne cięcie i szycie pod kontrolą wzroku, mniejsza utrata krwi, krótsza hospitalizacja, bardzo dobre efekty w zakresie powrotu potencji i trzymania moczu [9]. W 2012 Tewari i wsp. opublikowali dużą retrospektywną analizę prac poświęconych prostatektomii radykalnej [10]. Autorzy przeanalizowali łączenie 286876 prostatektomii: 167184 otwartych, 57303 laparoskopowych i 62389 robotowych. Wyniki onkologiczne, niezależnie od metody operacji, były porównywalne. Liczba powikłań, takich jak: reoperacja, uszkodzenie odbytnicy, moczowodu, zakrzepowe zapalenie żył głębokich, krwiaki, torbiel chłonna, nieszczelność zespolenia, przetoki moczowe czy ropienie rany były najrzadziej spotykane przy zastosowaniu techniki robotowej (tab. II).

W swojej metaanalizie autorzy wykazali, iż odsetek pozytywnych marginesów chirurgicznych jest podobny, niezależnie od zastosowanej techniki prostatektomii radykalnej. Natomiast zastosowanie techniki robotowej pozwala najskuteczniej ograniczyć liczbę powikłań śród- i pooperacyjnych (tab. II).

We wrześniu 2011 r. w Pasadenie w Stanach Zjednoczonych odbyła się konferencja ekspertów poświęcona robotowej radykalnej prostatektomii [11]. Wzięli w niej udział między innymi: Mani Menon, Vipul R. Patel, Walter Artibani, Francesco Montorsi, Vincenzo Ficcara i Alexandre Mottrie. Spotkanie to miało na celu podsumowanie wyników pierwszego dziesięciolecia zastosowania techniki robotowej w leczeniu raka stercza i sformułowanie wniosków. Panel zakończył się opracowaniem zaleceń i wytycznych dotyczących techniki operacyjnej, wyników onkologicznych i czynnościowych. Oto niektóre z nich:

- nie ma absolutnych przeciwwskazań do zastosowania techniki robotowej w prostatektomii radykalnej,

— otyłość, wcześniejsze operacje w obrębie jamy brzusznej czy duża objętość stercza nie są przeciwwskazaniami, tacy pacjenci powinni być operowani przez najbardziej doświadczonych urologów „robotowych”,

- limfadenektomia rozszerzona może być wykonywana podczas prostatektomii robotowej równie skutecznie, jak podczas operacji techniką otwartą,

Tabela II. Częstość występowania powikłań po klasycznej, laparoskopowej i robotowej radyklanej prostatektomii

\begin{tabular}{|c|c|c|c|}
\hline Technika/powikłanie & Otwarta & Laparoskopowa & Robotowa \\
\hline Zgon & $0,1 \%$ & $0,04 \%$ & $0,04 \%$ \\
\hline Reoperacja & $2,3 \%$ & $1,9 \%$ & $0,9 \%$ \\
\hline Uszkodzenie moczowodu & $1,5 \%$ & $0,2 \%$ & $0,1 \%$ \\
\hline Uszkodzenie odbytnicy & $0,5 \%$ & $1 \%$ & $0,3 \%$ \\
\hline Torbiel chłonna & $3,2 \%$ & $1,7 \%$ & $0,8 \%$ \\
\hline Nieszczelność zespolenia cewkowo-pęcherzowego & $10 \%$ & $3,7 \%$ & $3,5 \%$ \\
\hline Zwężenie zespolenia cewkowo-pęcherzowego & $2,2 \%$ & $0,8 \%$ & $0,9 \%$ \\
\hline Ropienie rany & $2,8 \%$ & $0,7 \%$ & $0,7 \%$ \\
\hline
\end{tabular}


- odsetek pozytywnych marginesów chirurgicznych jest porównywalny niezależnie od techniki prostatektomii ( robotowej, laparoskopowej, otwartej),

- prostatektomia robotowa nie wiąże się ze zwiększonym odsetkiem pacjentów wymagających terapii uzupełniającej,

- przeżycie wolne od wznowy biochemicznej po prostatektomii robotowej jest porównywalne z przeżyciem po zastosowaniu innych technik,

- dostępne dane wskazują na wyższość techniki robotowej, jeśli chodzi o zachowanie potencji i kontynencji.

W roku 2013 Porpiglia i wsp. opublikowali wyniki jednego z pierwszych randomizowanych badań porównujących prostatektomię laparoskopową i robotową [12]. Autorzy nie stwierdzili istotnych różnic w zakresie śród- i pooperacyjnych powikłań. Odsetek pacjentów trzymających mocz był wyższy w grupie operowanej techniką robotową: $80 \%$ po 3 miesiącach i $95 \%$ po roku. W grupie chorych poddanych prostatektomii laparoskopowej było to odpowiednio 61,6\% i $83,3 \%$. Tak więc zachowanie potencji było częstsze po operacji robotowej niż po laparoskopowej — 80\% i 54,2\%.

Zastosowanie robota chirurgicznego da Vinci w urologii stało się już powszechne, zwłaszcza w USA i Europie Zachodniej. Ta nowoczesna technika przyniosła korzyść zarówno operowanym pacjentom (mniej powikłań, szybszy powrót potencji i trzymania moczu), jak i operującym lekarzom (doskonała wizualizacja pola operacyjnego w trójwymiarze, dziesięciokrotne powiększenie, eliminacja drżenia rąk, wygodna pozycja podczas operacji). Według niektórych autorów także koszty społeczne leczenia są niższe: dzięki skróceniu czasu hospitalizacji chorych, ich szybszemu powrotowi do pracy i codziennej aktywności oraz obniżeniu kosztów leczenia powikłań [13]. Może to być ważnym argumentem przemawiającym za coraz szerszym wprowadzaniem tej techniki operacyjnej również w Polsce.

\section{Chirurgia onkologiczna}

Robot chirurgiczny jest również z powodzeniem stosowany w leczeniu nowotworów przewodu pokarmowego. Największa liczba doniesień w piśmiennictwie dotyczy le- czenia raka jelita grubego. Publikowane dotąd dane wskazują, że robot chirurgiczny znajduje zastosowanie w leczeniu pacjentów z rakiem odbytnicy. Zalety robota chirurgicznego są najbardziej zauważalne w leczeniu guzów dolnej i środkowej części odbytnicy, u pacjentów otyłych, pacjentów po przedoperacyjnej radioterapii oraz u pacjentów z wąską męską miednicą mniejszą [14, 15]. W badaniach porównawczych resekcji odbytnicy wykonywanych techniką robotową i laparoskopową operacje robotowe zachowują zalety chirurgii małoinwazyjnej, takie jak mniejszy ból pooperacyjny i krótszy pobyt w szpitalu. Ponadto związane są z mniejszą utratą krwi i mniejszym odsetkiem konwersji do operacji klasycznej oraz porównywalnym procentem powikłań [16-18]. Doskonały wgląd w pole operacyjne i precyzyjne narzędzia robotowe w rękach doświadczonego chirurga pozwalają operować z dużą dokładnością, zaoszczędzeniem struktur naczyniowych i nerwowych. W piśmiennictwie dostępne są publikacje potwierdzające, że zastosowanie robota w operacjach odbytnicy związane jest z lepszymi wynikami czynnościowymi, tj. z mniej nasilonymi zaburzeniami mikcji i funkcji seksualnych, jak również bardziej kompletnym preparatem mezorektum [19-21]. W najnowszym badaniu Kang i wsp. z Yonsei University w Korei przeanalizowali retrospektywnie 495 pacjentów z rakiem środkowej i dolnej części odbytnicy, operowanych sposobem klasycznym, laparoskopowym i robotowym [22].W każdej grupie znalazło się po 165 pacjentów. Badane grupy pacjentów były stosownie dobrane i porównywalne w zakresie danych demograficznych orazzaawansowania procesu nowotworowego. Wyniki badania potwierdziły, że operacje wykonywane techniką małoinwazyjną zapewniają większą radykalność onkologiczną niż operacje wykonywane techniką klasyczną. W grupie robotowej uzyskano mniej dodatnich marginesów okrężnych niż w grupie operowanej sposobem klasycznym ( $p=0,034)$. Ponadto u pacjentów operowanych robotowo i laparoskopowo częściej wykonano operacjęz zaoszczędzeniem zwieraczy, rzadziej występowały infekcje ran pooperacyjnych i pooperacyjne zaburzenia mikcji (tab. III). W trakcie 2-letniej obserwacji w badanych grupach nie znaleziono istotnych różnic w zakresie przeżyć bez wznowy choroby nowotworowej.

Tabela III. Porównanie wybranych parametrów okołooperacyjnych u chorych na raka odbytnicy, operowanych techniką klasyczną, laproskopową i robotową ( Kang i wsp.)

\begin{tabular}{|c|c|c|c|c|}
\hline & $\begin{array}{c}\text { Operacja } \\
\text { klasyczna (OS) }\end{array}$ & $\begin{array}{c}\text { Operacja } \\
\text { laparoskopowa (LS) }\end{array}$ & $\begin{array}{c}\text { Operacja } \\
\text { robotowa (RS) }\end{array}$ & $\mathrm{p}$ \\
\hline Operacje z zaoszczędzeniem zwieraczy & $89,7 \%$ & $95,8 \%$ & 99,4 & $<0,001$ \\
\hline Dodatnie marginesy okrężne & $10,3 \%$ & $6,7 \%$ & 4,2 & RS vs OS $(p=0,034)$ \\
\hline Zakażenia rany pooperacyjnej & $4,8 \%$ & $1,2 \%$ & $0,6 \%$ & $\begin{array}{c}0,050 \\
\text { RS vs OS }(p=0,037)\end{array}$ \\
\hline Długość pobytu w szpitalu, dni & $16,0 \pm 8,6$ & $13,5 \pm 9,2$ & $10,8 \pm 5,5$ & $<0,001$ \\
\hline Zaburzenia mikcji & $8,5 \%$ & $4,2 \%$ & $2,4 \%$ & $\begin{array}{c}0,034 \\
\text { RS vs OS }(p=0,015)\end{array}$ \\
\hline
\end{tabular}




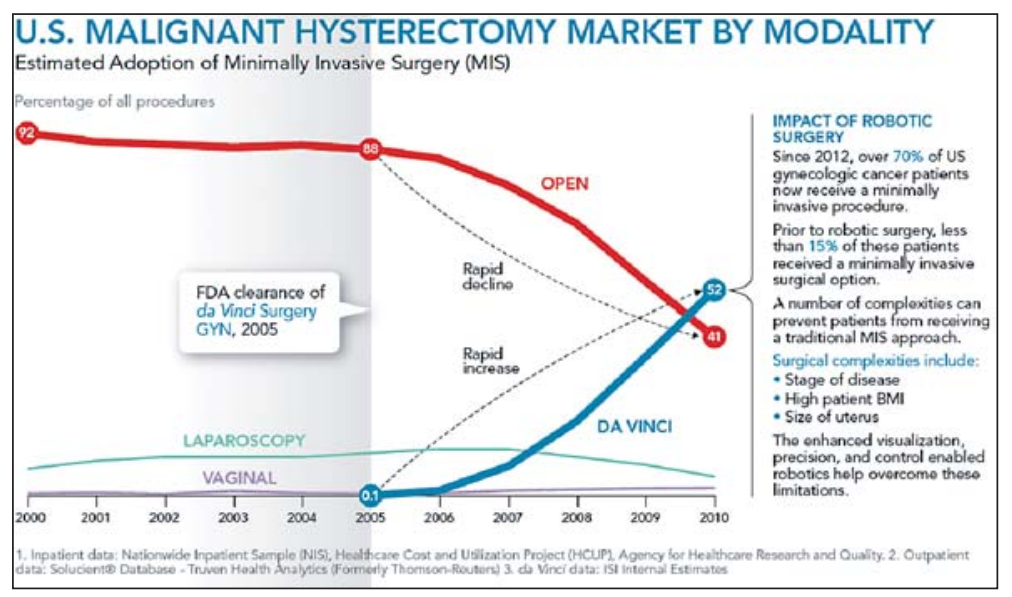

Rycina 4. Wpływ stosowania technologii robotowej na częstość wykonywania procedur małoinwazyjnych w ginekologii onkologicznej

Niezmiennie jednym z głównych argumentów przeciwko zastosowaniu robota w chirurgii onkologicznej pozostają wysokie koszty operacji robotowych. Pobyt w szpitalu pacjenta operowanego z zastosowaniem robota jest o 20-30\% droższy niż pacjenta operowanego metodą laparoskopową [23-25]. Wynika to głównie z wysokiej ceny systemu da Vinci oraz kosztów jego eksploatacji.

Należy podkreślić, że cytowane powyżej dane nie pochodzą z badań randomizowanych. Nie powinno to być jednak używane jako argument przeciwko technologii robotowej. System da Vinci jest stosowany w leczeniu chorych na raka odbytnicy od zaledwie kilku lat, stąd brak jest jeszcze wyników badań randomizowanych. Obecnie prowadzone są dwa wieloośrodkowe prospektywne badania randomizowane porównujące wyniki leczenia chorych na raka odbytnicy metodą robotową, laparoskopową i otwartą $[26,27]$. Wyniki tych badań pozwolą ostatecznie zweryfikować rolę robotyki w leczeniu chorych na raka odbytnicy.

\section{Ginekologia}

W ostatnich latach obserwujemy dynamiczny wzrost w zastosowaniu chirurgii robotowej w ginekologii. Ginekologia jest polem największego zastosowania chirurgii robotowej [28, 29]. Ogółem 1/3 histerektomii w USA jest wykonywanych technikami małoinwazyjnymi (ok. 200 000/rok), a 500 specjalistów ginekologii onkologicznej w USA kończy przynajmniej 1 kurs chirurgii robotowej rocznie [30, 31]. Według jednego z ekspertów, prof. Jana Perssona z Lund w Szwecji, roboty powinny służyć głównie do ginekologicznych operacji onkologicznych w dużych ośrodkach. Istnieją jednak również wskazania w przypadkach łagodnych, jak np. chorobliwa otyłość, endometrioza, skomplikowana histerektomia. Przy obecnych kosztach procedur robotowych, nie jest dobrym pomysłem użycie robota do prostych procedur w niewielkich liczbach. Będzie to kosztowne, przyniesie straty i da w rezultacie więcej powikłań [32].
Z najnowszych doniesień wynika, iż w Stanach Zjednoczonych odsetek operacji histerektomii wykonywanych małoinwazyjnie ciągle wzrasta. W związku z wprowadzeniem technologii robotowej do praktyki klinicznej w ginekologii, ponad połowa pacjentek z rakiem układu ginekologicznego jest obecnie operowana w sposób małoinwazyjny. Wcześniej zaledwie 15\% operacji ze wskazań onkologicznych w ginekologii było wykonywanych laparoskopowo lub przez dostęp pochwowy. Od roku 2010 większość operacji ginekologicznych jest przeprowadzanych z asystą robota da Vinci (ryc. 4).

W rozwoju robotowej chirurgii ginekologicznej znaczną rolę odgrywają względy komercyjne [33]. W Stanach Zjednoczonych powstały liczne centra chirurgii robotowej, jak np. Global Robotic Institute w Celebration na Florydzie. Centra te zwykle są związane z dużymi szpitalami, ale oferują głównie operacje robotowe ze wskazań małoinwazyjnych i onkologicznych [22].

W opublikowanych ostatnio pracach porównawczych wykazano, że w latach 2007-2010 liczba histerektomii robotowych zwiększyła się z 0,5\% do 9,5\%. Histerektomia z użyciem robota była droższa, jeśli chodzi o koszty szpitalne, w porównaniu z operacją otwartą jak i laparoskopową (odpowiednio 8854, 6712, 6671 dolarów).

Odsetek powikłań w przypadku histerektomii laparoskopowych i robotowych był podobny $(5,3 \%$ vs 5,5\%; $p=0,47)$. Podobnie przedstawiają się też wyniki powikłań śródoperacyjnych związanych z miejscem operowanym oraz powikłań ogólnomedycznych [34].

W marcu 2013 American College of Obstetrician and Gynecologist wydał oświadczenie, w którym przestrzega przed nieuzasadnionym zastosowaniem techniki robotowej. Pacjentki powinny być poinformowane, że histerektomia w asyście robota jest najlepsza w nietypowych i trudnych sytuacjach klinicznych, gdzie udowodniono, że wyniki są lepsze w porównaniu z zastosowaniem standardowych metod minimalnie inwazyjnych [35]. 


\section{Wnioski}

Chirurgia robotowa jest nową, dynamicznie rozwijającą się gałęzią chirurgii małoinwazyjnej. Według obecnego stanu wiedzy zastosowanie robota jest uzasadnione w kompleksowych operacjach wykonywanych w trudno dostępnych okolicach anatomicznych, jak na przykład w miednicy mniejszej. W Stanach Zjednoczonych operacje radykalnej prostatektomii z powodu raka stercza oraz histerektomii ze wskazań onkologicznych są wykonywane częściej z użyciem robota niż innymi technikami chirurgicznymi. Dokonujący się na naszych oczach postęp technologiczny daje nadzieję na kolejne lepsze i tańsze wersje robotów chirurgicznych, które powinny pojawić się na blokach operacyjnych w najbliższej przyszłości.

Biorąc pod uwagę wszystkie korzyści wynikające z zastosowania systemu chirurgicznego da Vinci, opisane w doniesieniach z całego świata, a także doświadczenia własne, z pełną odpowiedzialnością mogę stwierdzić, iż robot chirurgiczny nie jest gadżetem. Jest to naturalny, innowacyjny etap rozwoju chirurgii i techniki. Granicą tego rozwoju jest granica naszej wyobraźni.

Istotnym jest, abyśmy przekroczyli bariery, które dotychczas wstrzymywała postęp w tej dziedzinie w naszym kraju, a które stanowią nasze „polskie dylematy":

1. Za postęp trzeba na początku zapłacić, często z pozoru bardzo dużo. Z pozoru - bo nie liczy się wszystkich kosztów wyleczenia pacjenta.

2. Dążymy do tego, żeby być rozpoznawanym w Europie i na świecie, a nie stać nas na to, aby pokazać, że jesteśmy się w stanie rozwijać?

3. Czy poprawna moralnie jest sugestia, że polska chirurgia nie jest gotowa na postęp?

4. Jak doszło do sytuacji, w której polscy pacjenci płacą za nowoczesne procedury za granicą i jest to postępowanie moralnie dobre, a zapłacenie za te same procedury w Polsce jest postępowaniem moralnie złym?

Nasze dotychczasowe doświadczenia z robotem chirurgicznym da Vinci pozwalają przypuszczać, że roboty chirurgiczne będą w przyszłości powszechnie stosowane na salach operacyjnych i staną się jednym z podstawowych narzędzi chirurgii małoinwazyjnej. Roboty będą używane do kompleksowych operacji z zakresu chirurgii ogólnej, onkologicznej, urologicznej, ginekologicznej, torakochirurgii, transplantologii i kardiochirurgii. Operacje tego typu wymagają niezwykłej dokładności, preparowania i zaopatrywania dużych naczyń krwionośnych oraz szycia delikatnych struktur. Wraz z rozpowszechnieniem się robotyki rola laparoskopii zostanie ograniczona do mniej skomplikowanych operacji, takich jak usunięcie pęcherzyka żółciowego, wyrostka robaczkowego lub naprawa przepukliny. Klasyczna otwarta technika chirurgiczna pozostanie jednak podstawową metodą operacyjną, szczególnie w takich obszarach jak chirurgia urazowa lub naczyniowa [36].

\section{Prof. dr hab. n. med. Wojciech Witkiewicz}

Ośrodek Badawczo-Rozwojowy

Wojewódzki Szpital Specjalistyczny

ul. H. Kamieńskiego 73a, 51-124 Wrocław

e-mail:sekretariat@wssk.wroc.pl,Golda@wssk.wroc.pl

\section{Piśmiennictwo}

1. Witkiewicz W, Gawora P. Dlaczego robot chirurgiczny da Vinci jest potrzebny dla rozwoju polskiej medycyny — pierwsze polskie doświadczenia z zakresu chirurgii robotowej w Wojewódzkim Szpitalu Specjalistycznym we Wrocławiu, w Ośrodku Badawczo-Rozwojowym. Kardiochirurgia i Torakochirurgia Polska 2011; 8: 383-386.

2. Witkiewicz W. 112. Dwuletnie doświadczenia operacyjne z wykorzystaniem robota chirurgicznego da Vinci. Konferencja Najnowsze Osiągnięcia w Chirurgii. Poznań 2013.

3. Witkiewicz W, Zawadzki M, Rząca M i wsp. Robot-assisted right colectomy: Surgical technique and review of literature. Videosurgery Miniinv (e-pub, ahead of print).

4. Witkiewicz W. Robot chirurgiczny da Vinci - historia, teraźniejszość i przyszłość. Pierwsze polskie doświadczenia. III Kongres Onkologii Polskiej, Wrocław 2012.

5. Witkiewicz W, Rząca M i wsp. Specyficzne cechy wycięcia odbytnicy z zastosowaniem robota chirurgicznego da Vinci. XVIII Zjazd Polskiego Towarzystwa Chirurgii Onkologicznej, Warszawa, 2012.

6. Witkiewicz W, Zawadzki M. Co nowego w chirurgii robotowej? Jak skuteczniej leczyć raka odbytnicy? III Konferencja Naukowa, Bydgoszcz 2012.

7. WitkiewiczW, Zawadzki M. i wsp. Establishing the first robotic colorecta program in Poland - Initial experience and limitations for the Polish National Health System. 4th annual World Wide Congress on Clinical Robotics and Surgical Innovation, Chicago 2012

8. Witkiewicz W, Jastrzębski J, Sokołowski J, Fiutowski M, Horęzga J. Chirurgia robotowa - historia rozwoju. Przegląd Urologiczny 2011/12/6 (70).

9. davincisurgery.com.

10. Tewari A, Sooriakumaran P, Bloch DA, Seshadri-Kreaden U, Hebert AE, Wiklund $P$. Positive surgical margin and perioperative complication rates of primary surgical treatments for prostate cancer: a systematic review and meta-analysis comparing retropubic, laparoscopic, and robotic prostatectomy. Eur Urol 2012; 62: 1-15.

11. Montorsi F, Wilson TG, Rosen RC i wsp.; Pasadena Consensus Panel. Best practices in robot assisted radical prostatectomy: Recommendations of the Pasadena consensus panel. Eur Urol 2012; 62: 368-381.

12. Porpiglia F, Morra I, Lucci Chiarissi M i wsp. Randomised controlled tria comparing laparoscopic and robot-assisted radical prostatectomy. Eur Urol 2013; 63: 606-614

13. Liberman D, Trinh QD, Jeldres $C$ i wsp. Is robotic surgery cost-effective: yes. Curr Opin Urol 2012; 22: 61-65.

14. Scarpinata R, Aly EH. Does robotic rectal cancer surgery offer improved early postoperative outcomes? Dis Colon Rectum 2013; 56: 253-262.

15. Zawadzki M, Velchuru V, Albalawi Si wsp. Is hybrid robotic laparoscopic assistance the ideal approach for restorative rectal cancer dissection? Colorectal Dis 2013 Mar 25. doi: 10.1111/codi.12209. [Epub ahead of print].

16. Trastulli S, Farinella E, Cirocchi R i wsp. Robotic resection compared with laparoscopic rectal resection for cancer: systematic review and meta-analysis of short-term outcome. Colorectal Dis 2012; 14: e134-56.

17. Yang $Y$, Wang F, Zhang P i wsp. Robot-assisted versus conventional laparoscopic surgery for colorectal disease, focusing on rectal cancer: a meta-analysis. Ann Surg Oncol 2012; 19: 3727-3736.

18. Memon S, Heriot AG, Murphy DG i wsp. Robotic versus laparoscopic proctectomy for rectal cancer: a meta-analysis. Ann Surg Oncol 2012 19: 2095-2101.

19. Kim JY, Kim NK, Lee KY i wsp. A comparative study of voiding and sexual function after total mesorectal excision with autonomic nerve preservation for rectal cancer: laparoscopic versus robotic surgery. Ann Surg Oncol 2012; 19: 2485-493.

20. Luca F, Valvo M, Ghezzi TL i wsp. Impact of robotic surgery on sexual and urinary functions after fully robotic nerve-sparing total mesorectal excision for rectal cancer. Ann Surg 2013; 257: 672-678.

21. Baik SH, Kwon HY, Kim JS i wsp. Robotic versus laparoscopic low anterior resection of rectal cancer: short-term outcome of a prospective comparative study. Ann Surg Oncol 2009; 16: 1480-1487.

22. Kang J, Yoon KJ, Min BS i wsp. The impact of robotic surgery for mid and low rectal cancer: a case-matched analysis of a 3-arm comparison-open, laparoscopic, and robotic surgery. Ann Surg 2013; 257: 95-101. 
23. Baek SJ, Kim SH, Cho JS, Shin JW Kim J. Robotic versus Conventional Laparoscopic Surgery for Rectal Cancer: A Cost Analysis from A Single Institute in Korea. World J Surg 2012; 36: 2722-2729.

24. deSouza AL, Prasad LM, Park JJ i wsp. Robotic Assistance in Right Hemicolectomy: Is There a Role? Dis Colon Rectum 2010; 53: 1000-1006.

25. Park JS, Choi GS, Park SY i wsp. Randomized clinical trial of robot-assisted versus standard laparoscopic right colectomy. BrJSurg 2012;99: 1219-1226.

26. Collinson FJ, Jayne DG, Pigazzi A i wsp. An international, multicentre, prospective, randomised, controlled, unblinded, parallel-group trial of robotic-assisted versus standard laparoscopic surgery for the curative treatment of rectal cancer. Int J Colorectal Dis 2012; 27: 233-241.

27. http://clinicaltrials.gov/ct2/show/NCT00726622.

28. Hibner M, Marianowski P, Szymusik I i wsp. Zastosowanie robotów w chirurgii ginekologicznej. Ginekol Pol 2012; 83: 934-938.

29. Nezhat C, Lavie O, Lemyre M i wsp. Robot-assisted laparoscopic surgery in gynecology: scientific dream or reality? Fertil Steril 2009; 91: 2620-2622.

30. Advincula AP. Robotic surgery in gynecology. Foreword. Clin Obstet Gynecol 2011; 54: 373-375.
31. Holloway RW, Ahmad S. Robotic-assisted surgery in the management of endometrial cancer. J Obstet Gynaecol Res 2012; 38: 1-8.

32. Geppert B, Lönnerfors C, Persson J. Robot-assisted laparoscopic hysterectomy in obese and morbidly obese women: surgical technique and comparison with open surgery. Acta Obstet Gynecol Scand 2011; 90: 1210-1217.

33. Andrew M. Kaunitz. The Promotion of Robotic Gynecologic Surgery by Hospitals: Are Our Patients Being Misled? Disclosures Oct 12, 2012. Medscape Ob./Gyn.

34. Wright JD, Ananth CV, Lewin SN i wsp. Robotically assisted vs laparoscopic hysterectomy among women with benign gynecologic disease. JAMA 2013; 309: 689-698.

35. Statement on Robotic Surgery by ACOG President James T. Breeden; http://www.acog.org.

36. Releases/2013/Statement an Robotic Surgery Published March 14 2013. Accessed March 18.2013.

37. Witkiewicz W, Turek J, Zawadzki M. Czy roboty zdominują chirurgię XXI wieku? W: Leniowska L, Nawrat Z (red.) Postępy robotyki medycznej. Uniwersytet Rzeszowski 2013. 